\title{
Front Matter: Volume 11400
}

, "Front Matter: Volume 11400," Proc. SPIE 11400, Pattern Recognition and Tracking XXXI, 1140001 (22 May 2020); doi: 10.1117/12.2572651

SPIE. Event: SPIE Defense + Commercial Sensing, 2020, Online Only 


\title{
PROCEEDINGS OF SPIE
}

\section{Pattern Recognition and Tracking XXXI}

\author{
Mohammad S. Alam \\ Editor
}

27 April - 8 May 2020

Online Only, United States

Sponsored and Published by

SPIE

Volume 11400 
The papers in this volume were part of the technical conference cited on the cover and title page. Papers were selected and subject to review by the editors and conference program committee. Some conference presentations may not be available for publication. Additional papers and presentation recordings may be available online in the SPIE Digital Library at SPIEDigitalLibrary.org.

The papers reflect the work and thoughts of the authors and are published herein as submitted. The publisher is not responsible for the validity of the information or for any outcomes resulting from reliance thereon.

Please use the following format to cite material from these proceedings:

Author(s), "Title of Paper," in Pattern Recognition and Tracking XXXI, edited by Mohammad S. Alam, Proceedings of SPIE Vol. 11400 (SPIE, Bellingham, WA, 2020) Seven-digit Article CID Number.

ISSN: 0277-786X

ISSN: 1996-756X (electronic)

ISBN: 9781510635777

ISBN: 9781510635784 (electronic)

Published by

SPIE

P.O. Box 10, Bellingham, Washington 98227-0010 USA

Telephone +1 3606763290 (Pacific Time) · Fax +1 3606471445

SPIE.org

Copyright (C) 2020, Society of Photo-Optical Instrumentation Engineers.

Copying of material in this book for internal or personal use, or for the internal or personal use of specific clients, beyond the fair use provisions granted by the U.S. Copyright Law is authorized by SPIE subject to payment of copying fees. The Transactional Reporting Service base fee for this volume is $\$ 21.00$ per article (or portion thereof), which should be paid directly to the Copyright Clearance Center (CCC), 222 Rosewood Drive, Danvers, MA 01923. Payment may also be made electronically through CCC Online at copyright.com. Other copying for republication, resale, advertising or promotion, or any form of systematic or multiple reproduction of any material in this book is prohibited except with permission in writing from the publisher. The CCC fee code is 0277 $786 \mathrm{X} / 20 / \$ 21.00$

Printed in the United States of America by Curran Associates, Inc., under license from SPIE.

Publication of record for individual papers is online in the SPIE Digital Library.

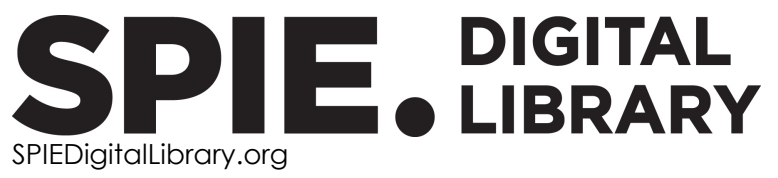

Paper Numbering: Proceedings of SPIE follow an e-First publication model. A unique citation identifier (CID) number is assigned to each article at the time of publication. Utilization of CIDs allows articles to be fully citable as soon as they are published online, and connects the same identifier to all online and print versions of the publication. SPIE uses a seven-digit CID article numbering system structured as follows:

- The first five digits correspond to the SPIE volume number.

- The last two digits indicate publication order within the volume using a Base 36 numbering system employing both numerals and letters. These two-number sets start with 00, 01, 02, 03, 04, 05, 06, 07, 08, 09, 0A, OB ... 0Z, followed by 10-1Z, 20-2Z, etc. The CID Number appears on each page of the manuscript. 


\section{Contents}

SESSION 1 NOVEL PATTERN RECOGNITION TECHNIQUES

$1140003 \quad$ Adaptation of Koschmieder dehazing model for underwater marker detection [11400-2]

1140005 Evolutionary clustering for dynamic partitioning of transportation network [1 1400-4]

\section{SESSION 2 TARGET TRACKING}

1140006 Transforming unstructured voice and text data into insight for paramedic emergency service using recurrent and convolutional neural networks [11400-6]

\section{SESSION $3 \quad$ NEURAL NETWORKS}

1140009 Vision system with deep learning classifiers for automatic quality inspection [1 1400-9]

11400 OA Image denoising using convolutional neural network [11400-10]

11400 OB Novel receipt recognition with deep learning algorithms [1 1400-1 1]

\section{SESSION 5 PATTERN CLASSIFICATION}

11400 ol Classification based on fast and robust approximations to order statistics [11400-18]

11400 0J Real-time holographic heterodyne spatial filtering [1 1400-19]

11400 OK Real-time holographic deconvolution for image differentiation [1 1400-20]

11400 OM Emergent pattern detection algorithm for big data streams [1 1400-22]

\section{SESSION 6 DEEP LEARNING}

11400 ON Underwater exploration by AUV using deep neural network implemented on FPGA [1 1400-23]

1140000 Selection of CPU scheduling dynamically through machine learning [1 1400-24] 
11400 OP Detection of moving human using optimized correlation filters in homogeneous environments [1 1400-25]

\section{SESSION 7 TARGET DETECTION}

11400 OS Adaptive high speed targets recognition systems controlled by the image's parameters [11400-28]

11400 OU SRVAE: super resolution using variational autoencoders [11400-30]

11400 OV Low-complexity DST approximation for VVC standard using particle swarm optimization [1 1400-31]

\section{POSTER SESSION}

11400 OX Comparative study on crowd counting with deep learning [1 1400-35] 